Bull. Fac . Agric., Cairo Univ.,65: 96-103 (2014).

\title{
NATURAL PARTHENOCARPIC FRUIT PRODUCTION IN \\ 'ANNA' APPLE CULTIVAR (Malus domestica cv. Anna)
}

(Received: 17.1.2014)

\author{
By \\ S. J. Owais \\ Department of Plant Production, Faculty of Agriculture, Mu'tah University, Karak, Jordan,
}

\begin{abstract}
In the current study, Anna apple cv. showed parthenocarpic tendency; shriveled seeded fruits and non-seeded fruits were observed. The results showed that self-pollination and open-pollination with Anna cv. pollens released in the same field lead to parthenocarpic fruits, while artificial crosspollination with Golden Dorset cv. gave comparably seeded fruits. Moreover, metrological data revealed that entirely seedless fruits developed under high temperatures prevailing during blooming time of Anna cv. Seedless fruits seemed to develop with stimulus pollination. The parthenocarpic fruits showed an elongated form and ring shape near the apical region. In conclusion, the results obtained in this study indicate that Anna cv. has an interesting parthenocapic property, which might addresses problems related to pollinator requirements.
\end{abstract}

Key words: apple, cross-pollination, open-pollination, parthenocarpy, self-pollination.

\section{INTRODUCTION}

Fruit development is the final stage of a continuous physiological process that begins with successful pollination and fertilization of egg and ends with fruit set and consequently maturation and ripening. Successful fertilization is usually needed for fruit set and development, otherwise no fruit is formed (Al-Joumayly et al., 2010). Apples are largely self-incompatible and require cross-pollination, the self-incompatability being controlled by a multi-allelic gametophytic incompatibility system controlled in the pollen and stylar tissue (Frankel et al., 1977). Different apple cultivars have different S-alleles that control self-incompatibility (Sakurai et al., 2000). In order to produce commercial crops, most commercial cultivars must be grown with another cultivar as a pollinizer. In some cases such as those in tomato, pepper, citrus and guava, however, parthenocarpic fruits may be genetically or environmentally control (e.g. extreme temperatures) or might be regulated by increased levels of plant hormones such as Auxins and Gibberellins in ovaries (Gustafson, 1942; Teaotia et al., 1961; Nagar and Rajarao, 1981; Talon et al., 1990, 1992; Varoquaux et al., 2000; Fos et al., 2001; Bhardwaj et al., 2005; Mesejo et al., 2013), which can replace pollination and stimulate fruit development. On the other hand, at the genetic level, several apple
(Malus domestica) mutants (Rae Ime, Spencer Seedless and Wellington Bloomless) are already known that lead to develop a parthenocarpic fruit and they are controlled by a single recessive gene (Yao et al., 2001).

So far, little information focuses on the effect of high temperature on parthenocarpic fruits in apple. Therefore, the tendency of parthenocarpic fruit formation in Anna apple was examined in relation to different pollination methods and the possible effect of high temperature during the blooming time.

\section{MATERIALS AND METHODS}

Twenty single productive trees of Anna apple were selected at the agricultural research station, Mu'tah University, Karak, Jordan for the purpose of this study during two successive growing seasons (2010 and 2011). Fifteen years old Anna used, were budded on MM106 (Malus domestica Borkh.) rootstock, semi vigorous, approximate height 2.5-3 meters in height and received the same agricultural practices. The apple trees were fertilized with $30 \mathrm{~kg}$. compost/tree in winter (in January) and then compound fertilizer (20:20:20 TE) was added in four doses, each $400 \mathrm{~g} /$ tree. The compound fertilizer was applied in the following stages: two weeks before balloon stage, two weeks after fruit set, and two doses during fruit development. The trees were 
irrigated three times (50 1 /tree) using drip irrigation after compound fertilizer application. The soil of the experimental site is characterized by having a sandy loam texture soil (56\% sand, $15 \%$ silt, $29 \%$ clay), alkaline $\mathrm{pH}$ (about 8.1), $1.3 \%$ organic matter, $640 \mathrm{ppm}$ total nitrogen $(\mathrm{N}), 18 \mathrm{ppm}$ available Olsen phosphorus $(\mathrm{P}), 22$ $\%$ calcium carbonate, CEC of 52.7 milliequivalent $(\mathrm{mEq}) \quad 100 \mathrm{~g}^{-1}$, and electrical conductivity $(1: 1)$ of $0.4 \mathrm{dS} \mathrm{m}^{-1}$. Anna cv. can produce good crop under desert conditions due to its low chilling requirements (Rokba 1985). The experiment was consisted of three treatments: self-pollination, open-pollination and cross-pollination (i.e. artificial/manual pollination treatment). Cross-pollination treatment performed by crossing Anna with Golden Dorsit pollen grains, while open pollination occured only within Anna trees. Selfpollination was performed by bagging spurs with white mesh at the balloon stage to prevent any possible fertilization with foreign pollens. Four different branches for each tree and each pollination treatment were selected in different directions on the periphery of the tree. For crosspollinated treatment, spurs were emasculated at the balloon stage and cross pollination with Golden Dorsit pollen grains was done at the full bloom stage and the spurs were then re-bagged after pollination. The pollen grains from Golden Dorsit were obtained from the National Center for Agricultural Research and Extension (NCARE), Shoubak for cross pollination treatment. The pollen grains for Golden Dorsit were collected in the same season by bagging spurs at the balloon stage, and at full pink stage, flowers were collected and subsequently dried. Thereafter, anthers were separated from other flower parts to be ready for cross-pollination and then re-bagged after pollination. Bags for selfpollination and cross-pollinated treatments were removed two weeks after full bloom. Open pollination treatment was represented by leaving four branches without bagging.

Pollen grain germination test was conducted using a germination medium consisted of $15 \%$ sucrose and two grams of agar placed in Petridishes, then pollen grains were spread on the medium. Thereafter, the Petri-dishes were incubated at $20{ }^{\circ} \mathrm{C}$ for two days (Pinney and Polito, 1990). For each cultivar, three fields from each of the three Petri-dishes were chosen in order to determine the number of germinated pollen grains under light microscope and were presented as a percentage.
Fruit set percentage for open and cross pollination was recorded three weeks after full bloom drop according to the following formula (Westwood, 1979):

$$
\text { Fruit set } \%=\frac{\text { Number of fruit set }}{\text { Number of fruit clusters }} X 100
$$

Five fruits from each replicate from four directions for each treatment (i.e. each experimental unit was represented by 20 fruits) were selected from each direction to record the number of seeds per fruit and pomological traits such as fruit weight $(\mathrm{g})$, fruit length $(\mathrm{L})$ and width (D) (cm), and fruit shape (L/D). Moreover, some chemical related traits were recorded: total soluble solids and acidity. The mean of fruit weight $(\mathrm{g})$ was recorded using electrical balance and average fruits' length and width $(\mathrm{cm})$ were taken with a caliper to determine the fruit shape (LD). Total soluble solids (TSS) were recorded by using hand refractometer and total acidity was measured by titrating $5 \mathrm{ml}$ of the fruit juice sample with $0.1 \mathrm{~N}$ $\mathrm{NaOH}$.

The experimental design was a Randomized Complete Block Design (RCBD). The experiment was replicated twenty times (i.e. data were taken from 20 trees from 4 branches selected at four directions). Data were analyzed by one way analysis of variance using the SAS program, and the differences between the means were compared using Fisher's least significant difference (LSD) at $\mathrm{P} \leq 0.05$ (Steel and Torrie, 1980).

\section{RESULTS AND DISCUSSION 3.1. Pollen grain germination}

The germination percentage for Anna and Golden Dorsit was significantly $(\mathrm{P}<0.01)$ different, the highest value was $77.6 \%$ for Anna cultivar and was lower for Golden Dorsit (64.2\%). These findings might indicate the genetic variation in this trait among apple cultivars.

\subsection{Fruit set}

Pollinating Anna with Golden Dorsit gave high percentage of fruit set indicating that the cross-pollination was more efficient to improve fruit set than the open and self-pollination treatment in the two successive growing seasons. Fruit se $t \%$ in the two successive seasons for cross-pollination was in average $54.45 \%$ and $52.83 \%$ in 2010 and 2011, respectively (Table 1). These values were significantly higher 
compared to fruit set\% of both self- (fruit set $=18.07 \%$ and $9.75 \%$ in the two successive growing seasons, respectively) and openpollination fruit set $=4.89 \%$ and $13.53 \%$ in the two successive seasons, respectively) treatments (Table 1). The high percentage of fruit set is normal for a crop like apple, where apple trees frequently set and retain excessive numbers of fruits in relation to tree size and leaf area (http://apples.hdc.org.uk/pdfs/section-

4.html.pdf?id=16/10/2013\%2016:30:51). This also is in accordance with other studies which showed high level of fruit set in apple grown with a pollinizer. For example different treatments (Zuniga-Guevara and Fischer,, 1992) including manual pollination, self- pollination, and natural (open) pollination showed that the numbers of fruits/tree were the best when Anna cultivar was crossed with Noyle or Quintanilla pollen. Wide range of genotypic variations in the percentages of fruit set with non-pollination have been reported as $72 \%$ in 'Ohrin' (Saito et al., 2007) and 48\% in 'Spencer Seedless' (Tanaka et al., 2004); the percentage of fruit set obtained in self- and cross-pollinated treatments in this study were much lower (range $=9.75$ $18.07 \%$ ), which might be due to complete self incompatibility if we take into account the seedless fruits obtained by both self- and crosspollination.

The low level of fruit set with parthenocarpic fruits with self- and open-pollination treatment and the high level of fruit set with seeded fruits when Anna was pollinated with Golden Dorsit is an evidence of the high tendency of selfincompatibility in Anna. Self- incompatability in apple is genetically regulated by selfincompatibility alleles at the $S$-locus carrying distinct specificity genes, one expressed in the pollen, and the other is expressed in the stylar tissue. Haploid carrying S-allele identical to those in the pistil will be rejected and consequently no fertilization will take place, however, any combination of different S-alleles will be compatible (Tassinari and Sansavini, 2005).

\subsection{Seed set}

Fruit development on normal apple flowers requires pollination for seed development. Normal apple fruit contains up to 10 seeds (Pratt, 1988), depending on the level of pollination. With manual pollination (cross-pollination), the number of seeds obtained in this study per fruit was 3.8 and 3.1 in the two successive seasons, respectively (Table 1). With self- and openpollination, fruits readily bear parthenocarpic fruits without seeds and/or shriveled seeds. The low number of seeds per fruit in the crosspollination treatment and the parthenocapic tendency in self- or cross-pollinated treatments might be due to partial or complete selfincompatibility system in Anna.

\subsection{Effect of pollination method on fruit characteristics}

The parthenocarpic fruits showed an elongated form and ring shape near the apical region similar to the characteristics described by Sampaio et al. (1983) for parthenocarpic fruits (Table 2). The mature seedless fruit was with high length/width ratio as compared with fruits obtained by cross pollination. The ratio of fruit length to fruit width (i.e. fruit shape) obtained from self- and open-pollination, was 1.2 compared to $<1.0$ for fruits harvested from cross-pollinated treatment (Table 2). The selfand open-pollination treatments exhibited

Table (1): Effect of different pollination methods on fruit and seed setting of Anna fruits.

\begin{tabular}{|c|c|c|c|c|}
\hline $\begin{array}{l}\text { Pollination } \\
\text { method }\end{array}$ & $\begin{array}{l}\text { Total number } \\
\text { of seeds }\end{array}$ & $\begin{array}{l}\text { Average Number } \\
\text { spores p }\end{array}$ & Number of fruits & $\%$ of fruit set \\
\hline Open & $\mathbf{0}^{\mathbf{a}}$ & $23.8^{\mathrm{a}}$ & $1.3^{b}$ & $4.9^{c}$ \\
\hline Self & $\mathbf{0}^{\mathbf{a}}$ & $21.1^{\mathrm{a}}$ & $3.3^{b}$ & $18.1^{b}$ \\
\hline Cross & $3.8^{b}$ & $21.1^{\mathrm{a}}$ & $10.8^{\mathrm{a}}$ & $54.5^{\mathrm{a}}$ \\
\hline LSD & 0.7851 & 5.4491 & 2.465 & 10.5 \\
\hline $\begin{array}{l}\text { Pollination } \\
\text { method }\end{array}$ & $\begin{array}{l}\text { Total number of } \\
\text { seeds }\end{array}$ & $\begin{array}{l}\text { Average Number } \\
\text { spores p }\end{array}$ & Number of fruits & $\%$ of fruit set \\
\hline Open & $\mathbf{0}^{\mathbf{b}}$ & $24.8^{\mathrm{a}}$ & $2.3^{\mathrm{b}}$ & $9.750^{b}$ \\
\hline Self & $\mathbf{0}^{\mathbf{b}}$ & $25.4^{\mathrm{a}}$ & $3.3^{b}$ & $13.538^{b}$ \\
\hline Cross & $3.1^{\mathrm{a}}$ & $23.1^{\mathrm{a}}$ & $11.6^{\mathrm{a}}$ & $52.830^{\mathrm{a}}$ \\
\hline LSD & 0.7433 & 8.412 & 2.742 & 10.158 \\
\hline
\end{tabular}


somewhat smaller average fruit weight as compared with those obtained by crosspollination indicating that cross-pollination has advantageous effect on the fruit size (Table 2). A comparative study of natural and artificial pollination of apple cv. 'Anna' in high regions of Costa Rica showed that in all treatments the average fruit weight was similar (Zuniga Guevara, 1992). Other studies showed that the parthenocarpic fruits obtained either by exogenous application of growth regulators or by preventing fertilization due to temperature fluctuation showed a deformed fruit shape (Bosland and Votava, 1999) and a reduced fruit size (Rylski, 1974). Seeds are usually formed, and the ovary and receptacle enlarge if pollination and fertilization occur normally in apples (Watanabe et al., 2008). There were no significant differences in fruit firmness and chemical characteristics between parthenocarpic and seeded fruits (Table 2). increase in day temperature during the blooming time; day/night temperature was $23-26 / 8-12{ }^{\circ} \mathrm{C}$ and $27-30 / 10-18{ }^{\circ} \mathrm{C}$ in 2010 and 2011 growing seasons, respectively (Fig. 1). While some authors showed that high temperature can stimulate parthenocarpy and lead to almost complete seedless fruits in tomato (Lin et al., 2014) and pepino (Solanum muricatum Aiton) (Ruiz and Nuez, 2000). In contrary, low temperature showed the ability of producing seedless fruits including apple (Dennis, 1967), tomato (Vardy et al., 1989 a and b) and pepper (Tiwari et al., 2011). Changing the endogenous level and external applications of plant growth regulators were found to be a likely cause for seedless fruits and development of parthenocarpic fruits in fruit crops. A close relation was observed between Gibberellins parthenocarpy in apples (Bukovac, 1963; Bukovac and Nakagawa, 1967; Nakagawa et al., 1968). Also gibberellins applied in a

Table (2): Effect of different pollination methods on some morphological traits and chemical characteristics of Anna fruits.

\begin{tabular}{|c|c|c|c|c|c|c|}
\hline \multirow[b]{2}{*}{$\begin{array}{l}\text { Pollination } \\
\text { method }\end{array}$} & \multicolumn{6}{|c|}{2010 growing season } \\
\hline & $\begin{array}{l}\text { Fruit length } \\
\text { (cm) }\end{array}$ & $\begin{array}{l}\text { Fruit } \\
\text { witdth } \\
\text { (cm) }\end{array}$ & $\begin{array}{l}\text { Fruit } \\
\text { shape }\end{array}$ & Firmness & $\begin{array}{l}\text { Total soluble } \\
\text { solids }\end{array}$ & Acidity \\
\hline Open & $6.52^{b}$ & $5.38^{b}$ & $1.212^{\mathrm{a}}$ & $10.9760^{\mathrm{a}}$ & $10.2600^{b}$ & $3.780^{\mathrm{a}}$ \\
\hline Self & $6.75^{\mathrm{ab}}$ & $5.478^{b}$ & $1.232^{\mathrm{a}}$ & $11.0920^{a}$ & $11.7360^{c}$ & $6.156^{\mathrm{a}}$ \\
\hline Cross & $6.9^{\mathrm{a}}$ & $7.43^{\mathrm{a}}$ & $\mathbf{0 . 9 2 8}^{b}$ & $10.4480^{b}$ & $11.9200^{a}$ & $4.342^{\mathrm{a}}$ \\
\hline LSD & 0.226 & 0.21 & 0.0364 & ns & ns & ns \\
\hline & \multicolumn{6}{|c|}{2011 growing season } \\
\hline $\begin{array}{l}\text { Pollination } \\
\text { method }\end{array}$ & $\begin{array}{l}\text { Fruit length } \\
(\mathrm{cm})\end{array}$ & $\begin{array}{l}\text { Fruit } \\
\text { witdth } \\
\text { (cm) }\end{array}$ & $\begin{array}{l}\text { Fruit } \\
\text { shape }\end{array}$ & Firmness & $\begin{array}{l}\text { Total soluble } \\
\text { solids }\end{array}$ & Acidity \\
\hline Open & $7.186^{\mathrm{a}}$ & $6.497^{b}$ & $1.106^{\mathrm{a}}$ & $9.87^{\mathrm{a}}$ & $13.00^{\mathrm{a}}$ & $3.925^{\mathrm{a}}$ \\
\hline Self & $6.698^{a}$ & $6.41^{b}$ & $1.04^{\mathrm{ab}}$ & $9.65^{\mathrm{a}}$ & $12.98^{\mathrm{a}}$ & $4.53^{\mathrm{a}}$ \\
\hline Cross & $6.858^{\mathrm{a}}$ & $7.130^{\mathrm{a}}$ & $0.972^{b}$ & $9.63^{\mathrm{a}}$ & $13.03^{a}$ & $4.21^{\mathrm{a}}$ \\
\hline LSD & 0.577 & 0.544 & 0.0992 & ns & ns & ns \\
\hline
\end{tabular}

\subsection{Effect of high temperature on parthenocarpy}

The present results revealed that a sudden increase in temperature during the blooming time was the likely cause for parthenocarpy, and consequently it could be concluded that the increase of temperature during the blooming time had a favorable effect on the production of parthenocarpic fruits. The blooming extended from the $8^{\text {th }}$ to the $15^{\text {th }}$ and from the $17^{\text {th }}$ to the $21^{\text {th }}$ of March in 2010 and 2011 cropping season, respectively. At the experimental site (Rabba Agricultural Station), there was an obvious combination with cytokinins (Bangerth and Schröder, 1994;) can induce seedless fruit production. Exogenous plant hormone application to unfertilized ovaries might serve as a switch that starts the continuing autonomous development of the fruit (Bangerth and Schröder, 1994), and controls the continuity of the flow of assimilates and nutrients required for fruit growth (Treharne et al., 1985). Parthenocarpy might also be cultivar dependent (Tassinari and Sansavini, 2005). This might also have switch-induced autonomous development of the fruit although the time at which this 

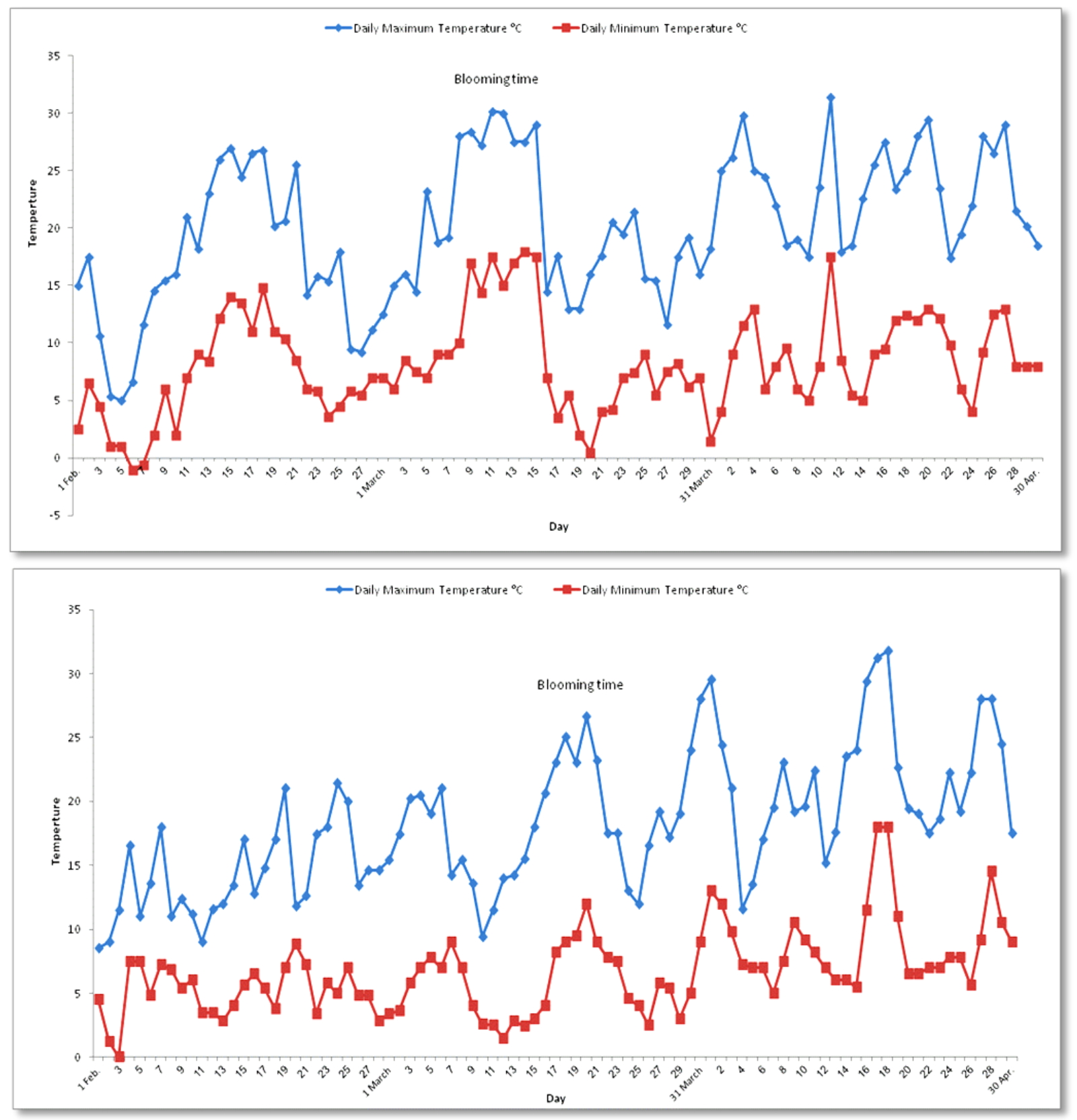

Fig. (1): Daily temperature from February to April during the two successive seasons, 2010 and 2011.

switch acts in naturally occurring parthenocarpic fruits remains unclear.

In some crop species such as tomato, high temperature stress reduces pollen grain number and germination (Aloni et al., 2001). In pepper, additional morphological changes are associated with high temperatures. Day/night temperatures of $28 / 23^{\circ} \mathrm{C}$ decreased ovary diameter and increased style length compared to a day/night temperatures of $23 / 18^{\circ} \mathrm{C}$ (Polowick and Sawhney, 1985). High temperature after anthesis also reduces fruit and seed growth and seed quality in chili pepper (Pagamas and Nawata, 2008).

Even though the parthenocarpic property could be an interesting property, which might address problems related to pollinator requirements, the initial fruit set and final commercial yield in apple trees are closely correlated in Anna cultivar. In our study, relying on self-pollination will decrease the proportion of fruit set per tree and in consequence the commercial yield per tree. Different pollination methods did not show any significant differences 
in firmness and total soluble solids and consequently might keep the qualities of apple fruits. In conclusion, Anna cv. displayed strong tendency for natural parthenocarpy where shriveled seeded fruits and non-seeded fruits were observed on trees handled with self and cross-pollination treatments. Our results indicate that high temperatures can induce parthenocarpic formation of Anna apple cv. when temperature is elevated during the blooming time. Anna cv. is self-incompatible but can be self-fruitful through the production of parthenocarpic fruits.

\section{REFERENCES}

Al-Joumayly A., Owais S. J. and Abdel-Ghani A. H. (2010). Effect of self, open and cross pollination on fruit set of three apple cultivars in south Jordan. Bulletin Faculty of Agriculture, Cairo University 61: 294298.

Aloni B., Peet M., Pharr M. and Karni L. (2001). The effect of high temperature and high atmospheric $\mathrm{CO} 2$ on carbohydrate changes in bell pepper (Capsicum аппиит) pollen in relation to its germination. Physiologia Plantarum 112: 505-512.

Bangerth F. and Schröder M. (1994). Strong synergistic effects of gibberellins with the synthetic cytokinin N-(2-chloro-4pyridyl)-N-phenylurea on parthenocarpic fruit set and some other fruit characteristics of apple. Plant Growth Reg., 15: 293-302.

Bhardwaj R. L., Meena R. R. and Mukherjee S. (2005). Role of plant growth regulator's in guava (Psidium guajava L.) - A review. Agric. Rev. 26: 281-287.

Bosland P. W. and Votava E. J. (1999). Peppers: vegetable and spice capsicums. In: Crop Production Science in Horticulture vol. 12, Wallingford, Oxon: CABI Publishing.

Bukovac M. J. (1963). Induction of parthenocarpic growth of apple fruit with gibberellin A3 and A4. Bot. Gaz. 124: 191-195.

Bukovac M. J. and Nakagawa S. (1967). Comparative potency of gibberellins in inducing parthenocarpic fruit growth in Malus sylvestris Mill. Experientia 23: 865.

Dennis F. G. and JR. (1967). Apple fruit-set: Evidence of specific role of seeds. Science 156: 71-72.

Fos M., Nuez F. and Garcia-Martinez J. L. (2000). The gene pat-2,which induces natural parthenocarpy, alters the gibberellin content in unpollinated tomato ovaries. Plant Physiol. 122: 471-480.

Frankel R., Galun E. and Linskens H.F. (1977). Allogamy. In: Frankel R., Galun E. and Linskens H. F. (eds.). Pollination mechanisms, reproduction and plant breeding. Springer- Verlag, New York. p. 67.

Gustafson F.G. (1942). Parthenocarpy: Natural and artificial. Bot. Rev. 8:599-654.

Lin S., George W. L. and Splittstoesser W. E. (2014). Parthenocarpy and the ability to set fruit under high temperature conditions (http://tgc.ifas.ufl.edu/vol32/vol32html/vo 132lin.htm.

Mesejo C., Yuste R., Martínez-Fuentes A., Reig C., Iglesias D. J. Primo-Millo E. and Agustí M. (2013). Self-pollination and parthenocarpic ability in developing ovaries of self-incompatible Clementine mandarins (Citrus clementina). Physiol Plant. 2013 148: 87-96.

Nagar P. K. and Rajarao T. (1981). Studies on Endogenous Cytokinins in Guava (Psidium guajava L.). Ann. Bot., 48: 845852.

Nakagawa S., Bukovac M. J., Hirata N. and Kurooka H. (1968). Morphological studies of gibberellin-induced parthenocarpic and asymmetric growth in apple and Japanese pear fruits. Journal of the Jap. Soc. for Hort. Sci.,37: 9-19.

Pagamas P. and Nawata E. (2008) Sensitive stages of fruit and seed development of chili pepper (Capsicum annuum L. var. Shishito) exposed to high-temperature stress. Scientia Horticulturae 117: 21-25.

Pinney K. and Polito, V. S. (1990). Olive pollen storage and in vitro germination. Acat Hort., 286: 207-211.

Polowick P. L. and Sawhney V. K. (1985). Temperature effects on male fertility and flower and fruit development in Capsicum annuиm L. Scientia Horticulturae 25: 117 27.

Pratt C. (1988). Apple flower and fruit: morphology and anatomy. Hort. Rev. 10: 273-308.

Rokba A. M. (1985). Progress report on promising fruit cultivars in Egypt. Acta Hort. (ISHS) 158:77-86.

http://www.actahort.org/books/158/158_8. $\underline{\mathrm{htm}}$. 
Ruiz J. J. and Nuez F. (2000). High temperatures and parthenocarpic fruit set: Misunderstandings about the pepino breeding system. The Journal of Hort.l Sci. and Biotech., 75: 161-166

Rylski I. (1974). Fruit set and development of several vegetable crops grown under low temperature conditions. Proc. $\mathrm{XIX}^{\text {th }}$ International Horticultural Congress Poland. III: 375-385.

Saito A., Fukasawa-Akada T., Igarashi M., Sato T. and Suzuki M. (2007). Selfcompatibility of 3 apple cultivars and identification of $\mathrm{S}$-allele genotypes in their self-pollinated progenies. Hort. Res. (Japan) 6:27-32.

Sakurai K., Brown S. K. and Weeden N. (2000). Self-incompatibility alleles of apple cultivars and advanced selections. HortScience, 35:116-119.

Sampaio V. R., Castro P. R. C., Olitta A. F. L. and Demétrio C. G. B. (1983). Effect of growth regulators on 'Anna'apple flowering. Acta Hort. (ISHS) 137:255260.

http://www.actahort.org/books/137/13728. htm.

Steel R. G. D. and Torrie J. H. (1980). Principles and procedures of statistics. $2^{\text {nd }}$ edition, McGraw Hill Comp., USA.

Talon M., Zacarias L. and Primo-Millo E. (1990). Hormonal changes associated with fruit set and development in mandarins differing in their parthenocarpic ability. Plant Physiol., 79:400-406.

Talon M., Zacarias L. and Primo-Millo E. (1992). Gibberellins and parthenocarpic ability in developing ovaries of seedless mandarins. Plant Physiol. 99:1575-1581.

Tanaka N., Komori S., Wada M., Bessho H., Abe K. and Suzuki A. (2004). Parthenocarpy ability of the class B mutation apple cultivars. J. Japan. Soc. Hort. Sci. 73 (Suppl. 1):203 (In Japanese).

Tassinari P. and Sansavini S. (2005). S-allele characterization in the gametophytic selfincompatibility pear system. In Tuberosa R., Phillips R. L., Gale M. (eds.), Proceedings of the International Congress. "In the Wake of the Double Helix: From the Green Revolution to the Gene Revolution", 27-31 May 2003, Bologna,
Italy, 303-308, C2005 Avenue media, Bologna, Italy.

Teaotia S. S., Pandey I. C. and Mathur R. S. (1961). Gibberellin induced parthenocarpy in guava Psidium guajava L.. Curr. Sci, 30: 312 .

Thinning flowers and fruitlets. http://apples.hdc.org.uk/pdfs/section-4. html.pdf?id=16/10/2013\%2016:30:51

Tiwari A., Vivian-Smith A., Voorrips R. E., Habets M. E. J., Xue L. B., Offringa R. and Heuvelink E. (2011). Parthenocarpic potential in Capsicum annuum $\mathrm{L}$. is enhanced by carpelloid structures and controlled by a single recessive gene. BMC Plant Bio., 11:143.

Treharne K. J., Quinlan J. D., Knight J. N. and Ward D. A. (1985). Hormonal regulation of fruit development in apple; A minireview. Plant Growth Reg. 3: 125-132.

Vardy E., Lapushner D., Genizi A. and Hewitt J. (1989a). Genetics of parthenocarpy in tomato under a low temperature regime I. Euphytica, 41:1-8.

Vardy E., Lapushner D., Genizi A. and Hewitt J. (1989b). Genetics of parthenocarpy in tomato under a low temperature regime II. Cultivar 'Severianin'. Euphytica 41:9-15.

Varoquaux, F., Blanvillain R., Delseny M. and Gallois P. (2000). Less is better: New approaches for seedless fruit production. Trends Biotechnol. 18:233-242.

Watanabe M., Segawa1 H., Murakami M., Sagawa S. and Komori S. (2008). Effects of Plant Growth Regulators on Fruit Set and Fruit Shape of Parthenocarpic Apple Fruits. J. Japan. Soc. Hort. Sci., 77 (4): 350-357.

Westwood, M. N. (1979). Temperate-zone pomology. W. H. Freedman and company. San Francisco, USA.

Yao J., Dong Y. and Morris B. A. (2001). Parthenocarpic apple fruit production conferred by transposon insertion mutations in a MADS-box transcription factor. PNAS, 98: 1306-1311.

Zuniga Guevara H. (1992). Comparative study of natural and artificial pollination of apple cv. Anna in a high altitude region of Costa Rica. Acta Horticulturae 310: 127134. 


\section{Anna العقد البكري في انتاج الثمار في صنف التفاح)}

(Malus domestica cv. Anna)

$$
\begin{aligned}
& \text { سائد جوزيف عويس } \\
& \text { قسم الانتاج النباتي ـ كلبة الزراعة ـ جامعة مؤنة ـ الكركـ الأردن }
\end{aligned}
$$

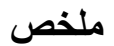

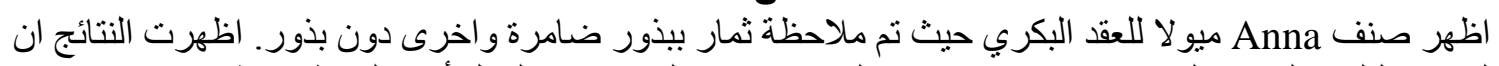

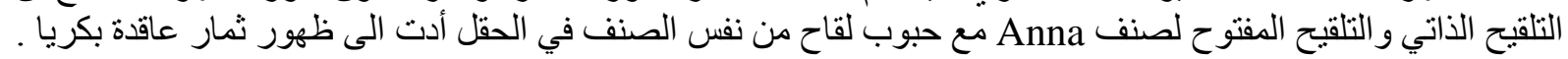

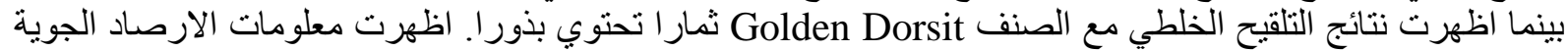

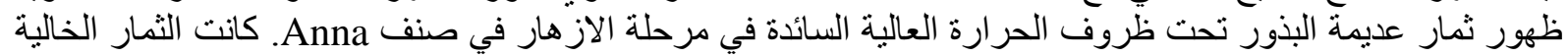

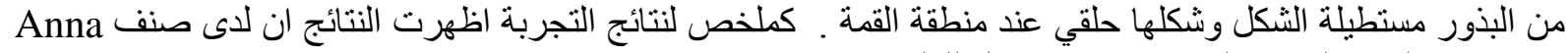

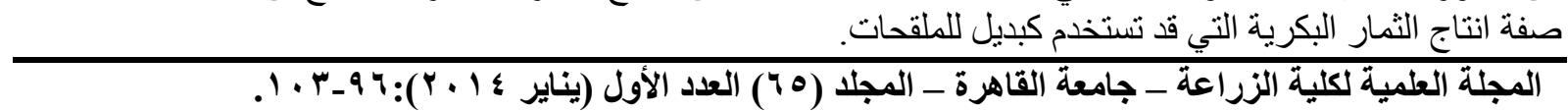

